\title{
Penokohan Film Sawung Kampret Karya Dwi Koendoro (Dwi Koen) Dalam Perspektif Strukturalisme
}

\author{
Dyah Gayatri Puspitasari \\ Universitas Bina Nusantara \\ Jl. K.H. Syahdan No. 9, Palmerah, Jakarta Barat 11480
}

\begin{abstract}
This research will discuss about the characterisation study of Sawung Kampret movie that was adapted from Legenda Sawung Kampret comics. Besides its distinctive position as the first study of comic adaptation movie in Indonesia, the most interesting fact is that both comic series and movie adaptation were produced and directed by the creator, Dwi Koendoro. Based on the thought of Ferdinand de Saussure, this study will focus on the relation of various elements in characterisation to construct a unity of the movie narrative structure. From this analysis, there was an interesting discovery that this comedy related with history, which enclosed the values of humanity and diversity of ethnic and culture. From this fact, Dwi Koendoro had confirmed that he was able to design new structural perspective by criticised the binary opposition in the old system. In conclusion, Sawung Kampret is a historical parody that also holds of ethical messages and nationalism excitement.
\end{abstract}

Keywords: movie, adaptation, character, structure, relation

\begin{abstract}
ABSTRAK
Tulisan ini berisi kajian penokohan film Sawung Kampret yang diadaptasi dari komik Legenda Sawung Kampret. Kajian ini menarik karena dua hal. Pertama, komik dan film adaptasinya diciptakan dan disutradarai oleh orang yang sama, yakni Dwi Koendoro. Kedua, kajian film yang diadaptasi dari komik Indonesia merupakan yang pertama. Melalui pendekatan struktural Ferdinand de Saussure, kajian berpusat pada relasi berbagai elemen penokohan yang membentuk keutuhan struktur narasi film. Didapat beberapa temuan menarik dimana unsur kelucuan pada penokohan film Sawung Kampret direlasikan dengan sejarah, hingga mampu membentuk narasi asosiatif yang mengusung nasionalisme berdasar nilai kemanusiaan, keberagaman etnis dan budaya. Fakta tersebut menunjukkan bahwa melalui film Sawung Kampret, Dwi Koendoro mampu menciptakan perspektif struktur baru dengan melakukan kritik terhadap struktur lama. Pasangan berlawanan (binary opposition) dalam sistem lama coba dipertanyakan. Sebagai hasil akhir maka dapat disimpulkan bahwa film Sawung Kampret merupakan film parodi sejarah yang sarat akan muatan pesan moral dan nasionalisme.
\end{abstract}

Kata kunci: film, adaptasi, penokohan, struktur, relasi 


\section{PENDAHULUAN}

Pada hakikatnya film merupakan media narasi visual, sebagai bentuk ekspresif, yang membentuk makna berdasarkan persepsi, baik berupa visual, gerak, audio, dan verbal. Di samping itu, film dapat dimaknai sebagai tafsir akan realitas, tampilan ruang dan waktu abstrak, yang memuat sikap, pandangan, serta berbagai tanggapan dan gagasan sutradaranya. Melalui film, seorang sutradara dapat menjadikan segala peristiwa sebagai suatu rangkaian suksesif dari satu adegan ke adegan lainnya. Melalui film pula, sebagaimana dikemukakan Lafevre, seorang sutradara mampu memberi dampak impresi realisme yang begitu besar pada pemirsa melalui gambar bergerak yang bersuara (2007:3).

Dalam menyampaikan cerita, film kerap menjadikan karya lain sebagai teks sumber. Genre ini disebut sebagai film adaptasi, yang dimaknai sebagai sebuah representasi dari sebuah karya yang telah terkenal sebelumnya. Sebagaimana Hutcheon, film adaptasi juga dipandang sebagai sebuah tindakan penyelamatan terhadap suatu karya original melalui sebuah tindakan kreatif dan interpretatif, dengan keterlibatan pengembangan intertekstual yang sesuai dengan teks sumbernya (2006:8).

Salah satu genre film adaptasi yang kian fenomenal hingga saat ini adalah film adaptasi komik. Hal ini jelas tampak pada keriuhan perkembangan film adaptasi komik Hollywood yang seolah tak pernah mengenal titik jenuh. Keriuhan ini lantas bukan sekedar kegaduhan pesta tanpa suatu perayaan prestasi. Deretan panjang catatan kesuksesan demi kesuksesan berhasil ditorehkan demikian fantastis hingga pada beberapa dekade terakhir ini (Gordon, 2007:vii). Bahkan banyak diantaranya berhasil keluar sebagai film-film box office, dan meraih beragam penghargaan di kancah perfilman internasional (Hand, 2009:87).
Keberhasilan sedemikian umumnya diraih oleh film-film yang mengangkat kisah tokoh-tokoh pahlawan super (super hero) komik-komik terkenal Marvel dan DC, seperti: Superman, Batman, X-Men, Spiderman, dan lain sebagainya. Walhasil perfilman dunia kian menjelajahi dan menjadikan dunia komik sebagai lahan subur bagi adaptasi dunia sinema kontemporer. Melalui keunggulan karakteristik gerak, audio visual serta kehandalan sutradara, film mampu memberi efek dramatis pada tokoh-tokoh komik yang dijadikan teks sumber. Popularitas tokoh-tokoh komik tersebut menjadi kian melesat, bahkan merasuki berbagai aspek kehidupan masyarakat kontemporer (Robinson, 2006:7).

Kendati tak segemerlap gempita perfiIman Hollywood, fenomena tersebut sempat pula menghiasi dunia perfilman Indonesia. Pada kurun waktu 1970-an hingga 1980-an, dunia perfilman Indonesia begitu diramaikan oleh berbagai film adaptasi komik yang mengangkat kisah para tokoh pendekar silat maupun pahlawan super karya para komikus terkenal Indonesia. Hal ini seiring dengan era keemasan dunia perkomikan Indonesia di tahun 1960-an hingga 1970-an (Dwi Koen, 2007: 50-51). Film Si Buta dari Gua Hantu (1970) yang diadaptasi dari komik dengan judul yang sama karya Ganes T.H., merupakan film yang fenomenal pada masanya (Wikipedia, 2014). Disusul kemudian oleh berbagai film adaptasi komik lainnya, seperti film Pandji Tengkorak (1971), Jaka Sembung (1981), Gundala Putera Petir (1981), dan lain sebagainya. Tak kalah dengan popularitas tokoh-tokoh super hero Barat, para tokoh pendekar silat dan pahlawan super lokal ini pun sempat digandrungi masyarakat Indonesia. ${ }^{1}$ Hal ini dapat dipahami, karena sebagaimana dikemukakan Pratista, bahwa tokoh merupakan kekuatan tersendiri dalam menarik perhatian pemirsa (2008:43). Ia menjadi peran sentral yang meniscayakan 
narasi asosiatif yang demikian melekat dalam benak pemirsa, hingga membentuk suatu 'kisah'nya tersendiri.

Namun seiring dengan waktu, kiprah film adaptasi komik Indonesia justru semakin redup, dan tak menentu (Kurniawan, 2012). Hingga di tahun 1996, tampak suatu upaya kebangkitan melalui penayangan film Sawung Kampret di Stasiun TV Surya Citra Televisi Indonesia (SCTV). Film ini dikemas dalam bentuk film serial layar kaca yang menyasar pangsa pasar remaja. Kisah yang diangkat mengetengahkan petualangan tokoh pendekar silat bernama Sawung Kampret. Dalam aksinya ia selalu didampingi seorang sahabat, yakni pendekar ko-

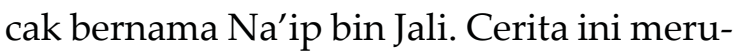
pakan adaptasi dari serial komik terkenal era 1990-an, yakni: komik Legenda Sawung Kampret. Baik komik maupun film adaptasinya diciptakan dan disutradarai oleh Dwi Koendoro (Dwi Koen), tokoh yang begitu dikenal dengan gaya sindiran dan kelakar yang khas pada tiap karyanya (Setiawan, 2002:59). Film ini sempat mendapat respon positif, dan membawa angin segar tersendiri. Namun masalah pendanaan menjadikan laju produksi film ini terhenti di episode ke-12. ${ }^{2}$

Selanjutnya produksi film adaptasi komik Indonesia dapat dikatakan mati. ${ }^{3}$ Oleh karena itu diperlukan berbagai ikhtiar untuk mengangkat kembali eksistensinya. Salah satunya adalah melalui studi lanjut yang mampu mengkaji film adaptasi komik Indonesia dari sudut pandang akademis. Hal ini penting, karena selain memberi dampak positif bagi perkembangan perfilman nasional, keberadaan film adaptasi komik mampu memberi dampak positif bagi bidang industri kreatif lainnya, khususnya komik (Gordon, 2007:x). Dengan kondisi sedemikian, karya-karya original serta nilai seni tradisi yang banyak terkandung dalam ragam cerita komik Indonesia ${ }^{4}$ niscaya terangkat dan terlestarikan.
Untuk menjawab permasalahan ini, dilakukan kajian dengan menempatkan film Sawung Kampret sebagai obyek penelitian. Film ini menarik, karena merupakan satusatunya film adaptasi komik Indonesia yang diperuntukkan bagi remaja, serta penyutradaraannya dilakukan oleh komikusnya sendiri. Dengan demikian akan dapat disimak bagaimana seorang Dwi Koen bercerita dan menyampaikan pesan, melalui tokoh-tokoh komik yang dihadirkan ke dalam bentuk film, dari penyajian still picture ke dalam bentuk motion picture. Selain itu dapat pula disimak bagaiman tafsir kongruenitas maupun inkongruenitas Dwi Koen atas realitas nyata, melalui unsur artifisial kekriyaan tokoh-tokohnya. Episode yang diangkat adalah Marietje Van der Bloemkool. Episode ini dipilih karena merupakan episode yang menghadirkan tokoh Marietje, putri bangsawan Belanda yang jatuh hati kepada tokoh Sawung Kampret. Hadirnya tokoh ini menarik karena mengandung dialog dua bangsa, dua budaya, hingga episode ini memiliki nilai kompleksitas lebih dibanding episode lainnya.

Adapun fokus kajian penelitian ini berpusat pada elemen terpenting struktur narasi film, yakni: penokohan (Pratista, 2008:43). Selanjutnya elemen-elemen pembentuk struktur penokohan, yakni: nama tokoh dan tokoh, akan dikaji dalam perspektif strukturalisme. Kajian berpusat pada struktur penokohan secara naratif, tanpa menyentuh wilayah kajian akan struktur visual maupun suara. Pada kerangka ini maka akan dianalisis bagaimana elemen-elemen struktur penokohan dalam film Sawung Kampret saling berelasi membentuk satu kesatuan narasi film yang utuh.

Penelitian ini penting sekaligus menarik, karena selain mengangkat film yang penyutradaraannya dilakukan oleh komikusnya sendiri, juga merupakan kajian pertama yang membahas tentang film adaptasi komik Indonesia dari sudut pandang aka- 
demis. Hal ini mengingat penelitian-penelitian sebelumnya lebih mengangkat film adaptasi komik luar negeri, atau pun film Indonesia yang diadaptasi dari karya-karya sastra. Dengan penelitian ini diharapkan mampu mengembalikan gairah film adaptasi komik Indonesia, hingga mampu menciptakan sinergi dari berbagai sektor industri kreatif lainnya, seperti: sektor industri komik, waralaba karakter film, maupun merchandise lainnya. Hal ini tentunya akan berujung pada optimalisasi tingkat laju pertumbuhan ekonomi Indonesia secara keseluruhan, dan sektor industri kreatif pada khususnya. Walhasil dapat semakin dipahami, bahwa masalah ini menjadi penting dan menarik untuk diangkat menjadi sebuah penelitian.

\section{METODE}

Pada dasarnya penelitian bersifat eksposisif, dengan menjelaskan berbagai analisis terhadap teks yang teraga dan tak teraga. Paradigma penilaian dan analisa struktural bersandar pada wawasan dan penafsiran berbasis literatur, teori, dan wawancara.

Dalam penelitian ini digunakan pendekatan struktural yang berbasis pada metode pemikiran Ferdinand de Saussure, hingga dapat memudahkan peneliti melihat film Sawung Kampret sebagai sebuah 'teks yang otonom'. Artinya, teks dianggap berdiri sendiri, sebagai sebuah struktur yang mengkonstruksi makna berdasar relasi antar elemen di dalamnya.

Berpijak pada pemahaman tersebut, kajian struktur terhadap film Sawung Kampret berpusat pada relasi berbagai elemen struktur dalam membentuk satu kesatuan karya film yang utuh. Tentu saja asosiasi-asosiasi makna yang dimungkinkan timbul karena relasi tersebut juga masuk ke dalam ruang lingkup kajian. Selanjutnya pada tahap

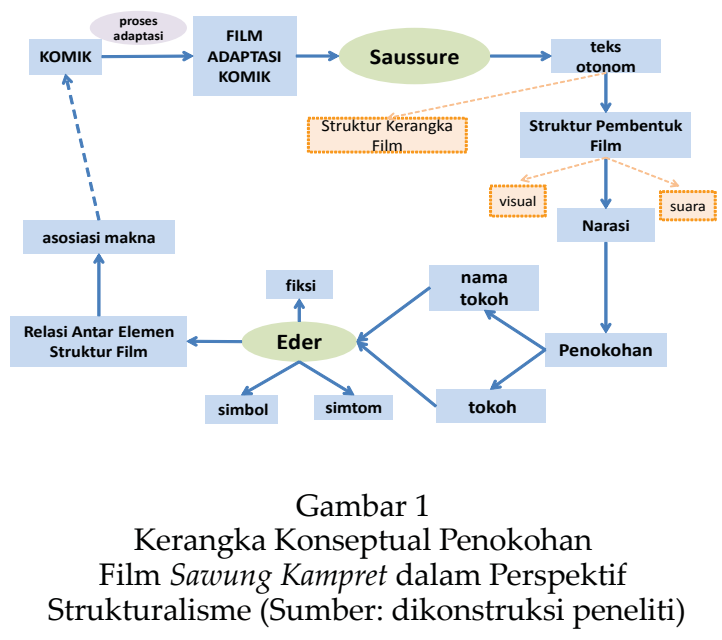

penguraian kerangka asosiasi makna yang dimungkinkan timbul, digunakan struktur konseptualisasi 'clock of character' Jens Eder sebagai teori pembantu.

Pada Gambar 1 tampak bahwa melalui pendekatan struktural Saussure, film adaptasi ditempatkan sebagai sebuah teks yang otonom. Secara dikotomis, film adaptasi akan terpilah menjadi dua struktur, yaitu struktur kerangka film dan struktur pembentuk film. Fokus penelitian ditujukan pada elemen-elemen struktur pembentuk film. Selanjutnya kajian akan berpusat pada elemen terpenting pembentuk struktur narasi film, yakni: penokohan. Melalui kaidah diakronis, relasi antar elemen pembentuk penokohan, yakni: tokoh dan nama tokoh, akan dianalisis, untuk dikaji kesesuaian (kompatibilitas) antar elemen dalam sebuah kombinasi sintagmatik sebagai syarat terbentuknya struktur yang berkesesuaian. Dikarenakan ruang lingkup telaah dua elemen tersebut tidak menyentuh wilayah pembahasan elemen struktur visual dan suara, maka pada tahap ini implementasi struktur konseptualisasi 'clock of character' Eder terbatas pada aspek fiksi, simbol, dan simtom, tanpa menyertakan aspek artifak (artifacts). Ketiga aspek ini akan menjadi kerangka asosiasi makna yang terbentuk melalui relasi antar elemen struktur film 
berdasar konsep sintagmatik paradigmatik. Dengan analisis sedemikian maka akan teridentifikasi bagaimana elemen-elemen struktur narasi penokohan film Sawung Kampret saling berelasi membentuk satu kesatuan narasi film yang utuh.

\section{HASIL DAN PEMBAHASAN}

Sebagaimana Pratista, penokohan merupakan elemen keutamaan naratif dalam struktur film (2008:43). Bahkan oleh Eder, penokohan ditegaskan sebagai peran sentral dalam memotivasi dan memberi muatan makna pada keseluruhan narasi film (2010:6). Seperti yang telah diuraikan sebelumnya, keutamaan analisis dalam penelitian ini mengacu pada perspektif strukturalisme yang ditujukan pada dua elemen penokohan, yakni: nama tokoh dan tokoh. Berdasar relasi sintagmatik paradigmatik, struktur ketiga aspek 'clock of character' Eder mampu mengurai kerangka asosiasi makna yang terbentuk dalam ruang lingkup fiksi (fictional being), simbol (symbol), dan simtom (symtomps). Dengan demikian tokoh-tokoh film Sawung Kampret dimaknai sebagai sosok dengan entitas ketubuhan akan identitas, mentalitas, perilaku, serta pemaknaan dan refleksi fenomena kultur sosial, yang saling berelasi membentuk keutuhan penokohan dalam keseluruhan struktur narasi film.

Berikut akan diurai bagaimana elemenelemen struktur naratif film Sawung Kampret saling berelasi dan membentuk berbagai asosiasi makna dan pesan.

\section{Film Sawung Kampret episode Marietje Van der Bloemkool}

Film Sawung Kampret episode Marietje Van der Bloemkool merupakan cerita aksi petualangan dua orang pendekar bersahabat: Sawung Kampret dan Na'ip bin Jali. Kisah di- hadirkan dengan latar belakang zaman VOC abad ke-17, seputar kurun waktu Gubernur Jenderal Jan Pieters Coen berkuasa. Dikisahkan, J.P Coen sibuk menyambut kedatangan bangsawan Belanda, Fritz Van der Bloemkool, yang akan berkunjung ke Batavia bersama putrinya, Marietje Van der Bloemkool. Marietje dikenal sebagai pencinta bunga. J.P. Coen lantas memerintahkan penjarahan bunga anggrek istimewa di kebun bang A'um, untuk dipersembahkan pada Marietje.

Di sisi lain, komplotan yang dipimpin Van Baskom, seorang bekas pegawai VOC yang dipecat J.P.Coen, merencanakan penculikan Marietje sebagai bentuk balas dendam terhadap J.P.Coen. Penculikan berhasil dilakukan, namun bunga anggrek terbawa oleh Marietje. Sawung berusaha merebut kembali bunga anggrek tersebut, dan di luar rencana, mampu menyelamatkan Marietje. Kericuhan pun berujung fitnah pada Sawung dan Na'ip sebagai penculik Marietje.

\section{Analisis Nama Tokoh dalam Narasi Peno- kohan Film Sawung Kampret}

Berdasar 'clock of character' Eder (2010), nama tokoh merupakan elemen identitas aspek fiksi (fictional being) tokoh film (2010: 23-32). Sebagai aspek fiksi, tampak bahwa nama-nama tokoh dalam film Sawung Kampret, dihadirkan dengan nama-nama lucu. Kata yang digunakan berasal dari ragam bahasa, yakni bahasa Indonesia, Belanda, Tionghoa, serta beberapa bahasa daerah seperti bahasa Jawa, Betawi, dan Sunda. Selain itu terdapat pula beberapa nama yang merupakan perpaduan dua kata bahasa yang berbeda, dan membentuk asosiasi lucu, seperti: Van Baskom, Van Tabock, Van Markapoetz, dan Van Sablon.

Melalui analisis lebih lanjut, dapat diperoleh pemahaman bahwa nama-nama tokoh tersebut tidak hanya berasosiasi lucu, namun lebih merupakan suatu upaya yang 
Tabel 1 Arti dan Asosiasi Nama Tokoh Film Sawung Kampret

\begin{tabular}{|c|c|c|c|}
\hline Nama Tokoh, Peran & Arti & Asosiasi Makna & Pesan \\
\hline $\begin{array}{l}\text { Sawung Kampret } \\
\text { (pendekar silat) }\end{array}$ & $\begin{array}{l}\text { Dalam bahasa Jawa: } \\
\text { Sawung memiliki dua arti. } \\
\text { Pertama: ayam jago, jago adu- } \\
\text { an. Kedua: sarung/kantong } \\
\text { pisau,atau parang (pedang). } \\
\text { Kampret: kelelawar. } \\
\text { Dalam bahasa Sunda: Sawung: } \\
\text { sarang. } \\
\text { Kampret: busana celana panjang } \\
\text { longgar pria (sontog), sebagai } \\
\text { sarang tempat 'burung laki- } \\
\text { laki'. }\end{array}$ & $\begin{array}{l}\text { Sawung: jago (keperkasaan), } \\
\text { pelindung. } \\
\text { Kampret (kelelawar): lincah dan } \\
\text { gesit. } \\
\text { Kampret (sontog): superioritas, } \\
\text { maskulinitas seorang pende- } \\
\text { kar. } \\
\text { Sawung Kampret: pendekar gesit } \\
\text { pemberani dengan kelihaian } \\
\text { jurus silat tak terkalahkan, ber- } \\
\text { hati mulia, dan senantiasa me- } \\
\text { lindungi sesama. }\end{array}$ & $\begin{array}{l}\text { Keperkasaan yang disertai nurani } \\
\text { sejatinya mampu mewujud sebagai } \\
\text { sosok pelindung yang mumpuni. }\end{array}$ \\
\hline $\begin{array}{l}\text { Marietje Van der } \\
\text { Bloemkool } \\
\text { (puteri bangsawan } \\
\text { Belanda) }\end{array}$ & $\begin{array}{l}\text { Marietje (bahasa Belanda): } \\
\text { nama yang biasa diberikan un- } \\
\text { tuk wanita Belanda. } \\
\text { Bloemkool (bahasa Belanda): } \\
\text { sayuran bunga kol, warna pu- } \\
\text { tih, menyerupai bunga mawar, } \\
\text { bertekstur keras. }\end{array}$ & $\begin{array}{l}\text { Bloemkool: keindahan, kelem- } \\
\text { butan, keteguhan. } \\
\text { Marietje Van der Bloemkool: } \\
\text { sosok perempuan lembut } \\
\text { cantik,namun memiliki kete- } \\
\text { guhan. }\end{array}$ & $\begin{array}{l}\text { Wanita bukan mahluk lemah. } \\
\text { Dibalik paras cantik dan kelembut- } \\
\text { annya, terhimpun kemuliaan dan } \\
\text { keteguhan tersendiri. }\end{array}$ \\
\hline $\begin{array}{l}\text { Van Baskom } \\
\text { (serdadu VOC yang } \\
\text { dipecat) }\end{array}$ & $\begin{array}{l}\text { Van (bahasa Belanda): kata sam- } \\
\text { bung nama orang Belanda. } \\
\text { Baskom (bahasa Indonesia): } \\
\text { mangkuk besar. }\end{array}$ & $\begin{array}{l}\text { Baskom: buruk, keserakahan } \\
\text { Van Baskom: sosok manusia ja- } \\
\text { hat dan tamak. }\end{array}$ & $\begin{array}{l}\text { Sifat jahat dan ketamakan menis- } \\
\text { cayakan manusia buruk. }\end{array}$ \\
\hline $\begin{array}{l}\text { Van Tabock } \\
\text { (serdadu VOC, kaki } \\
\text { tangan J.P Coen) }\end{array}$ & $\begin{array}{l}\text { Van (bahasa Belanda): kata sam- } \\
\text { bung nama orang Belanda. } \\
\text { Tabock (bahasa Betawi: tabok): } \\
\text { pukul. }\end{array}$ & $\begin{array}{l}\text { Tabock: kekerasan. } \\
\text { Van Tabock: sosok manusia yang } \\
\text { selalu bertindak dengan keke- } \\
\text { rasan. }\end{array}$ & $\begin{array}{l}\text { Seorang kaki tangan hanya mampu } \\
\text { bertindak dengan kekerasan. }\end{array}$ \\
\hline $\begin{array}{l}\text { Van Markapoetz } \\
\text { (serdadu VOC, kaki } \\
\text { tangan J.P. Coen) }\end{array}$ & $\begin{array}{l}\text { Van (bahasa Belanda): kata sam- } \\
\text { bung nama orang Belanda. } \\
\text { Markapoetz (bahasa Jawa: sema- } \\
\text { put): pusing, hampir mati. }\end{array}$ & $\begin{array}{l}\text { Markapoetz: kekacauan (chaos). } \\
\text { Van Markapoetz: sosok ma } \\
\text { nusia kacau dengan perilaku } \\
\text { membabibuta. }\end{array}$ & $\begin{array}{l}\text { Akal budi dan nurani seorang kaki } \\
\text { tangan selalu kacau, dan tindakan- } \\
\text { nya selalu membabibuta. }\end{array}$ \\
\hline $\begin{array}{l}\text { Van Sablon } \\
\text { (serdadu VOC, kaki } \\
\text { tangan J.P Coen) }\end{array}$ & $\begin{array}{l}\text { Van (bahasa Belanda): kata sam- } \\
\text { bung nama orang Belanda. } \\
\text { Sablon (bahasa Indonesia): ce- } \\
\text { takan. }\end{array}$ & $\begin{array}{l}\text { Sablon: duplikasi (replika). } \\
\text { Van Sablon: sosok replika titah } \\
\text { atasan, tanpa jati diri, tanpa } \\
\text { inisiatif. }\end{array}$ & $\begin{array}{l}\text { Seorang kaki tangan tidak pernah } \\
\text { memiliki dirinya sendiri, hanya } \\
\text { merupakan sosok replika titah } \\
\text { atasan. }\end{array}$ \\
\hline $\begin{array}{l}\text { Marutoklopo } \\
\text { (bangsawan pribu- } \\
\text { mi, kaki tangan } \\
\text { VOC) }\end{array}$ & $\begin{array}{l}\text { Marutoklopo (bahasa Jawa: } \\
\text { marut, dan kelopo). } \\
\text { Marut: memarut. } \\
\text { Kelopo: kelapa. }\end{array}$ & $\begin{array}{l}\text { Kelapa: kepala, akal budi, mar- } \\
\text { tabat. } \\
\text { Memarut kelapa: memarut ke- } \\
\text { pala, menghancurkan akal budi } \\
\text { dan martabat. }\end{array}$ & $\begin{array}{l}\text { Marutoklopo: sosok manusia tanpa } \\
\text { akal budi dan martabat. } \\
\text { Martabat, nalar, dan nurani seorang } \\
\text { bangsawan pengkhianat seperti } \\
\text { Marutoklopo ibaratnya diparut (di- } \\
\text { hancurkan) oleh hasrat kepenting- } \\
\text { an pribadi, yang lantas dipersem- } \\
\text { bahkan untuk penjajah. }\end{array}$ \\
\hline $\begin{array}{l}\text { Markutil (kaum } \\
\text { miskin pribumi, } \\
\text { mengabdi pada Van } \\
\text { Baskom) }\end{array}$ & $\begin{array}{l}\text { Markutil (bahasa Indonesia: } \\
\text { Kutil). } \\
\text { Kutil: bisul kecil }\end{array}$ & $\begin{array}{l}\text { Kutil: kecil, kecil hati, kenistaan, } \\
\text { penyakit. } \\
\text { Markutil: sosok manusia nista, } \\
\text { pesakitan nurani. }\end{array}$ & $\begin{array}{l}\text { Kaum miskin pengkhianat seperti } \\
\text { Markutil, tidak saja nista harta, na- } \\
\text { mun nista pula nurani dan marta- } \\
\text { batnya. }\end{array}$ \\
\hline $\begin{array}{l}\text { Doktor Van Klompen } \\
\text { (ilmuwan Belanda) }\end{array}$ & $\begin{array}{l}\text { Van (Bahasa Belanda): kata sam- } \\
\text { bung nama orang Belanda. } \\
\text { Klompen (bahasa Belanda): } \\
\text { sepatu, pelindung kaki. }\end{array}$ & $\begin{array}{l}\text { Klompen (sepatu): pelindung, } \\
\text { penentu arah langkah, kete- } \\
\text { guhan, kemuliaan. } \\
\text { Doktor Van Klompen: sosok } \\
\text { pelindung, teguh menuntut } \\
\text { ilmu, senantiasa mengarahkan } \\
\text { (membina) dan melindungi } \\
\text { sesama. }\end{array}$ & $\begin{array}{l}\text { Nilai kearifan dan kemuliaan terle- } \\
\text { tak pada keteguhan, dan kearifan } \\
\text { menuntut ilmu yang bermanfaat } \\
\text { membina dan melindungi sesama. }\end{array}$ \\
\hline
\end{tabular}


berikhtiar pada asosiasi pemaknaan dan pesan tertentu. Berikut hasil analisis dari beberapa nama tokoh dalam film Sawung Kampret episode Marietje Van der Bloemkool.

Dari hasil analisis Tabel 1 dapat disimak bahwa nama-nama tokoh dalam film Sawung Kampret bukan sekedar pilihan kata dengan asosiasi lucu, namun lebih merupakan struktur pembentuk narasi. Di samping itu, nama tokoh bukan sekedar

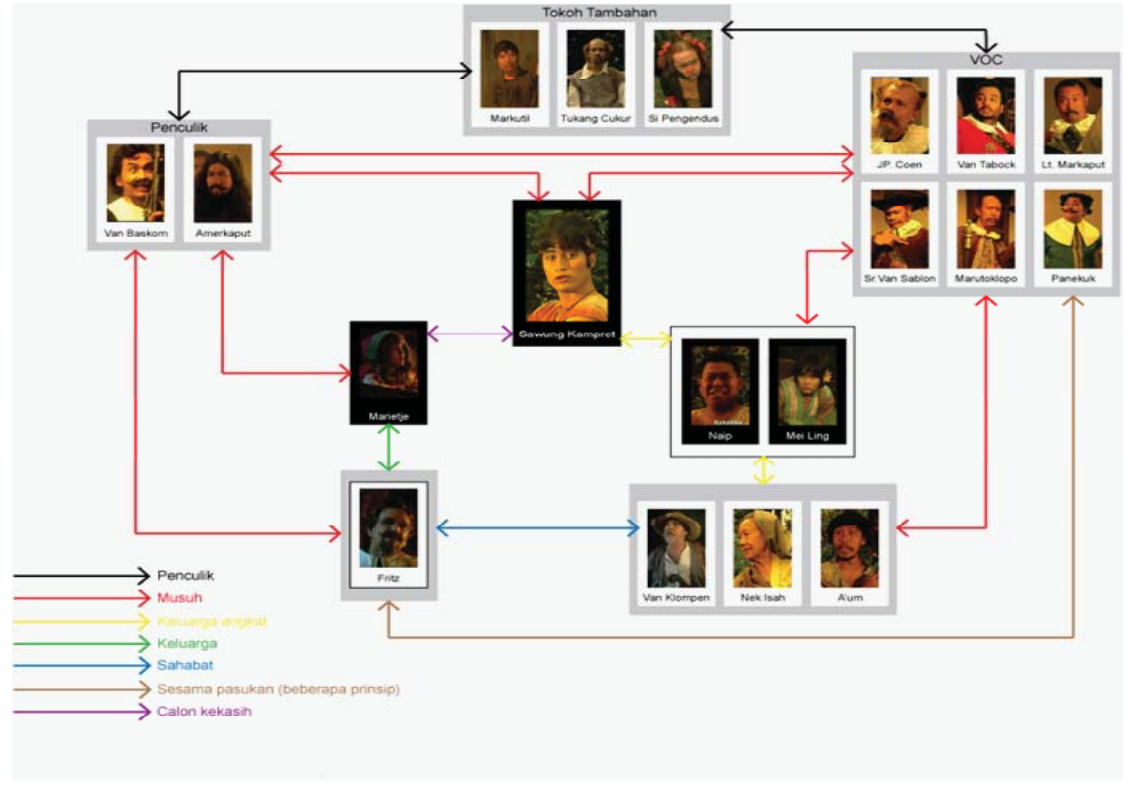

Gambar 2

Bagan relasi antar tokoh film Sawung Kampret episode Marietje Van der Bloemkool.

(Sumber: VCD Sawung Kampret, dikonstruksi peneliti April 2013) termaknai sebagai aspek fiksi (fictional being) seperti dalam penelitian Eder (2010:23), namun mampu termaknai sebagai aspek simbol (symbol) dengan bentukan berbagai asosiasi makna dan pesan.

Hal yang menarik untuk disimak adalah, asosiasi makna dan pesan tidak hanya terkandung dalam satu nama tokoh. Jika dicermati, tampak bahwa relasi antar nama beberapa tokoh mampu membentuk satu keutuhan pesan. Hal demikian dapat dijumpai pada ketiga nama serdadu VOC kaki tangan J.P Coen, yakni: Van Sablon, Van Tabock, dan Van Markapoetz. Jika arti dan asosiasi makna ketiga nama tokoh ini dipadupadankan, maka akan terbentuk suatu keutuhan pesan, bahwa seorang kaki tangan kejahatan adalah sosok replika titah atasan, tanpa jati diri, nalar, dan nurani, hingga hanya mampu bertindak dengan kekerasan dan menghadirkan kekacauan.

\section{Analisis Relasi Antar Tokoh dalam Keutuhan Narasi Film Sawung Kampret}

Dalam sebuah narasi, selain dengan pengungkapan langsung, sosok kepriba-

dian tokoh dapat dijelaskan pula dengan penokohan yang diungkapkan secara tidak langsung. Diantaranya yaitu melalui aksi yang dilakukan tokoh tersebut, bagaimana ia berpikir, serta bagaimana tokoh lain mengatakan atau berpikir tentang tokoh tersebut (Pratista, 2008:85). Dengan kata lain, kepribadian tokoh dapat disimak melalui relasi antar tokoh yang satu dengan yang lainnya. Berpijak pada pemahaman sedemikian, maka dilakukan analisis yang menyasar pada relasi antar tokoh dalam suatu kerangka relasi yang saling terkait secara sintagmatik paradigmatik, hingga membentuk semacam rangkaian suksesif yang mengarah pada peran tokoh sebagai aspek simbol maupun aspek simtom.

Bagan relasi pada Gambar 2 memberi gambaran relasi antar tokoh protagonis, antagonis, dan tritagonis dalam film Sawung Kampret episode Marietje Van der Bloemkool. Analisis pada tiap relasi, mampu memberi pemahaman akan keseluruhan struktur narasi, dan berbagai asosiasi makna dan pesan yang terbentuk. Sebagai contoh, akan diurai 
hasil analisis relasi yang berpusat pada tokoh protagonis Sawung Kampret dengan beberapa tokoh lainnya, seperti: $\mathrm{Na}$ 'ip bin Jali, Doktor Van Klompen, Marietje, dan Mei Ling. Berikut hasil analisis tersebut:

\section{Relasi Sawung - Na'ip}

Na'ip adalah saudara angkat sekaligus sahabat Sawung. Sawung dan Na'ip adalah duo pendekar silat tak terkalahkan. Kendati hampir selalu bertengkar, keduanya tak terpisahkan. Sawung adalah sosok agak pendiam, berdarah Aceh, Bugis, Padang, Batak, Madura, Ponorogo. Sedangkan Na'ip sebagai sosok kocak, asli Betawi campuran Sunda, Banten, Palembang, dan Banjarmasin.

\section{Analisis relasi:}

Melalui relasi antar tokoh ini, terbentuk asosiasi makna persaudaraan, nasionalisme dan kebhineka tunggal ikaan yang dimiliki bangsa Indonesia. Dua karakter berbeda yang disatukan menempatkan kedua tokoh tersebut sebagai aspek simbol nilai-nilai tersebut. Relasi ini mampu memberi pesan bahwa perbedaan berdasar semangat persaudaraan justru mampu berperan sebagai penyatu, pelengkap, dan penghimpun suatu keadidayaan. Dengan demikian selain kental dengan unsur humor, pada hakikatnya relasi ini mengingatkan bahwa kebhinekaan merupakan kekayaan tersendiri bangsa ini yang patut dijaga dan dipelihara. Melaluinya mampu terhimpun kemanunggalan adidaya dan semangat nasionalisme.

\section{Relasi Sawung - Doktor Van Klompen}

Doktor Van Klompen adalah kakek angkat sekaligus guru bagi Sawung. Biasa dipanggil Opa Klompen oleh Sawung. Opa Klompen adalah ilmuwan Belanda yang mencintai Nusantara. Selalu bertentangan dengan VOC karena membela kepentingan kaum pribumi. Sosoknya menjadi tauladan bagi
Sawung dalam mencintai ilmu pengetahuan, alam, sesama, hingga Sawung mampu menjadi seorang pendekar yang cerdas, menguasai berbagai bahasa, dan mencintai kegiatan bertani.

\section{Analisis relasi:}

Melalui relasi antar tokoh ini, terkandung asosiasi makna kearifan, ketauladanan, toleransi, serta kepedulian terhadap ilmu pengetahuan, alam, dan Tanah Air. Doktor Van Klompen dan Sawung Kampret merupakan aspek simbol dari nilai-nilai tersebut. Namun kecintaan Doktor Van Klompen yang begitu besar terhadap Nusantara, menempatkannya pula pada aspek simtom yang mengarah pada sindiran Dwi Koen atas kecenderungan ketidakpedulian bangsa ini terhadap kekayaan alam dan budaya negerinya sendiri. Sedangkan kasih sayang Opa Klompen (bangsa Belanda) terhadap Sawung (pribumi) mengandung pesan bahwa tidak semua bangsa Belanda adalah penjajah keji, dan bahwasanya pendidikan berdasar ketauladanan merupakan hal terpenting dalam pendidikan itu sendiri.

Jika diasosiasikan dengan kekinian, relasi ini tampak mampu membawa dua pesan penting. Pertama, kegiatan bertani yang dilakukan Sawung, menempatkan tokoh Sawung sebagai aspek simbol masyarakat agraris yang bermata pencaharian bertani. Hal ini membawa pesan bahwa bertani itu berbudaya. Kebertanian adalah salah satu sejarah utama kebudayaan dan peradaban bangsa ini - meminjam istilah Acep Iwan Saidi. Pesan demikian lantas menempatkan tokoh Sawung Kampret sebagai aspek simtom yang mengarah pada sindiran dan bentuk keprihatinan Dwi Koen atas sikap bangsa ini yang kian cenderung memarginalkan pertanian dalam kehidupan keseharian, bahkan bertani dimitoskan sebagai pekerjaan hina.

Sedangkan pesan penting kedua menyasar pada relasi antar kedua tokoh ini, yang mampu termaknai sebagai simbol seka- 
ligus simtom akan relasi Indonesia - Globalisasi. Pada konteks ini terkandung pesan bahwa globalisasi bukan ancaman. Bangsa Indonesia justru harus mampu mengambil manfaat positif, tanpa harus kehilangan potensi, dan kejatidiriannya. Melalui globalisasi seyogyanya bangsa ini mampu terus menerus memberi nilai baru pada nilai peradaban dan kebudayaan yang akarnya tertancap dalam sejarah - meminjam istilah Acep Iwan Saidi (2014).

\section{Relasi Sawung - Marietje}

Marietje adalah putri bangsawan Belanda, cantik, dan pencinta bunga. Ia diselamatkan Sawung dari tawanan penculik. Menganggap Sawung sebagai kakak kandung, juga buah hatinya. Ia selalu membela kaum pribumi. Jatuh hati pada Nusantara bahkan menganggapnya sebagai negeri kahyangan. Namun bagi Sawung, Marietje tidak cantik, bahkan identik dengan gambaran hantu yang kerap diceritakan mendiang neneknya, yakni berkulit pucat, mata biru, rambut kuning, dan hidung runcing. Pada pertarungan merebut kembali bunga anggrek, di luar rencana, Sawung menyelamatkan Marietje.

\section{Analisis relasi:}

Melalui relasi antar tokoh ini, terbentuk asosiasi makna kelembutan, kemuliaan, keteguhan, dan nilai integritas, yang menempatkan tokoh Marietje dan Sawung sebagai aspek simbol nilai-nilai tersebut. Hal ini lantas memberi pesan bahwa tidak semua bangsa bangsa Belanda adalah penjajah keji, dan dibalik kelembutan seorang wanita senantiasa tersimpan suatu kemuliaan dan keteguhan nurani. Kecintaan Marietje pada Nusantara mampu mengarah pada aspek simtom sindiran Dwi Koen akan krisis kepedulian bangsa ini terhadap negerinya. Apresiasi justru seringkali datang dari bangsa lain.

Relasi dimana kecantikan Marietje lebih dianggap sebagai sosok hantu oleh Sawung, bukanlah sekedar sentuhan humor sisi keluguan Sawung belaka. Jika dicermati, hal ini menyasar pada aspek simtom sindiran Dwi Koen atas fenomena makna cantik yang diacu masyarakat Indonesia dengan peran media (kapitalisme) terimplisit di sana. Melalui relasi ini sebenarnya Dwi Koen sedang mengingatkan bahwa nilai cantik tidak identik dengan kulit putih, rambut kuning, mata biru, dan hidung mancung. Otentitas nilai kecantikan wanita Timur perlu diapresiasi. Dengan demikian tampak di sini harapan seorang Dwi Koen, agar kesadaran demikian dimiliki masyarakat, guna mampu secara arif dan cerdas dalam menyikapi jejalan dogmatis mitos cantik yang kerap dilontarkan berbagai media pada era modern ini.

Berbagai pesan dapat pula disimak melalui aspek simbol tokoh Sawung. Keberhasilan Sawung merebut bunga anggrek dan menyelamatkan Marietje, hal ini mampu memberi pesan bahwa nilai keberanian dan keteguhan patut didasari perikemanusiaan tanpa memandang segala perbedaan dan faktor kepentingan.

Namun di samping bentukan asosiasiasosiasi makna dan pesan sedemikian, sebenarnya terdapat simtom menarik yang sangat penting untuk disimak. Jika ditilik lebih cermat, maka tampak bahwa pada hakikatnya relasi antar tokoh ini mengarah pada aspek simtom kritik Dwi Koen terhadap sistem pendidikan kekinian yang cenderung menjauhkan diri dari nilai-nilai lokal yang berbasis karakter budaya. Peran pentingnya kian tergeser oleh dominasi pendidikan formal yang mengatasnamakan kecerdasan modern. Di mata Dwi Koen, nilai kesejatian suatu pendidikan karakter harus senantiasa mampu berakar pada kebudayaan yang berikhtiar pada kepekaan nurani. Dengan demikian sudah sepatutnya pendidikan sedemikian dijadikan ruh bagi kependidikan itu sendiri. Berbagai sikap dan tindakan Sawung yang diketengahkan pada relasi ini, mampu termaknai sebagai pengejawantah- 
an keberhasilan pendidikan karakter budaya yang ditanamkan sejak dini. Peran penting pola asuh orangtua sekaligus terimplisit di sana. Walhasil melalui relasi ini, pada dasarnya Dwi Koen sedang mengingatkan, bahwa pendidikan karakter berbasis kebudayaan merupakan cikal bakal pembentuk nilai integritas yang mampu mencerdas muliakan generasi muda bangsa.

\section{Relasi Sawung - Mei Ling}

Mei Ling adalah gadis keturunan Tionghoa yang pandai silat, pandai meramu obatobatan dari berbagai jenis tanaman, dan mengagumi tokoh Cinderella. Ia adalah adik angkat Sawung dan Na'ip, yang secara sembunyi-sembunyi terus mengikuti dan melindungi sepak terjang kedua kakak angkatnya dalam menghadapi komplotan Van Baskom dan pasukan VOC.

\section{Analisis relasi:}

Melalui relasi antar tokoh ini, terkandung asosiasi makna ketulusan, keberanian, keteguhan, kecerdasan, toleransi, dan keberagaman. Tokoh Mei Ling dimaknai sebagai aspek simbol akan nilai-nilai tersebut. Kasih sayang Mei Ling selain merupakan aspek simbol akan sikap toleransi terhadap keberagaman, dapat pula dimaknai sebagai aspek simtom yang mengarah pada masalah kerukunan antar etnis Tionghoa dan pribumi di Indonesia. Permasalahan ini kerap menjadi isyu sensitif di tengah masyarakat. Oleh sebab itu melalui relasi ini tampak ajakan Dwi Koen pada sikap saling bijak memandang, bijak menilai, atas dasar persaudaraan, bukan semena-mena menghakimi atas dasar kebencian terhadap suatu perbedaan. Sedangkan relasi kekaguman Mei Ling terhadap tokoh Cinderella, dapat dimaknai sebagai aspek simtom sindiran dan keprihatinan Dwi Koen atas fenomena keterpurukan nasib tokoh-tokoh komik dan film lokal yang diserbu oleh arus deras to- koh-tokoh komik dan film-film impor yang masuk ke Indonesia.

\section{Kompatibilitas Nama Tokoh dan Relasi Antar Tokoh dalam Narasi Film Sawung Kampret}

Dari hasil kedua analisis yang telah diurai, maka tampak kompatibilitas antar elemen nama tokoh dan relasi antar tokoh dalam sebuah kombinasi sintagmatik yang membentuk struktur yang berkesesuaian. Sehingga dapat semakin disimak bahwa dalam penokohan film Sawung Kampret, Dwi Koen mampu mengetengahkan kedua elemen tersebut menjadi bukan sekedar sebagai aspek fiksi (fictional being). Lebih dari itu, keduanya mampu dimaknai sebagai aspek simbol dan aspek simtom yang mengandung muatan makna dan bentukan refleksitas atas fenomena kultur sosial kekinian. Jalinan kesesuaian ini selanjutnya mampu membentuk suatu kerangka asosiasi makna dan pesan melalui relasi antar elemen struktur penokohan tersebut. Pada akhirnya semakin tampak bahwa elemen-elemen struktur penokohan dalam film ini mampu saling berelasi membentuk satu kesatuan totalitas tutur akan rangkaian suksesif struktur narasi film Sawung Kampret yang beresonansi dengan komik teks sumbernya. Hal ini sebagaimana dikemukakan Beger, bahwa totalitas tutur sedemikian mampu membentuk kekuatan atmosfir dan ruh suatu karya yang mengacu pada teks sumbernya (2008:88).

Di samping itu, dari kedua analisis tersebut, dapat ditemukan pula beberapa hubungan struktur yang menarik, berupa hubungan pasangan berlawanan (binary opposition), hubungan keberagaman, dan relasi tokoh fiksi dan nonfiksi. Pada struktur binary opposition, analisis ini mampu memetakannya ke dalam beberapa aspek, yakni: aspek gender, aspek relasi kuasa (Belanda versus pribumi), dan aspek relasi antar ras (kulit putih versus kulit berwarna). 
Berikuturaian temuan beberapahubungan dengan struktur menarik tersebut:

\section{Hubungan Pasangan Berlawanan (bi- nary opposition)}

\section{a. Penjajah versus Yang Dijajah (Belanda versus Pribumi)}

Dalam perspektif konvensional, penjajah selalu merupakan pihak yang dianggap kejam. Belanda adalah musuh yang tidak berprikemanusiaan, dan pribumi sebagai kaum yang tertindas. Namun, dalam film ini Dwi Koen menghadirkan fakta bahwa tidak selamanya pihak yang dikategorikan penjajah tersebut, dalam hal ini Belanda, berperilaku kejam. Justru sebaliknya, Dwi Koen mengedepankan beberapa tokoh bangsa sendiri (pihak yang dijajah) yang justru lebih kejam dari Belanda, dan sebaliknya, dihadirkan beberapa tokoh Belanda yang justru membela pribumi dan mencintai Nusantara.

Sebagai contoh, hal sedemikian dapat disimak pada relasi tokoh J.P. Coen, Doktor Van Klompen, dan Marutoklopo yang membentuk suatu alegori yang menarik. Tokoh J.P Coen berbanding terbalik dengan tokoh Doktor Van Klompen yang mengutamakan masyarakat pribumi sebagai kaum terhormat dan berbudaya tinggi. Doktor Van Klompen turut menjaga dan melestarikan kebudayaan Nusantara, bahkan berani berkorban demi mempertahankan itu semua. Sedangkan tokoh Marutoklopo adalah bangsa pribumi yang justru berpihak pada VOC, dan menghancurkan simbol keluhuran bangsa dan budayanya sendiri demi harta dan kehormatan semu dari VOC.

\section{b. Laki-laki versus perempuan (kuat ver- sus lemah)}

Dari hasil analisis relasi antar tokoh yang telah diurai, tampak tokoh Mei Ling dihadirkan sebagai sosok pendekar perempuan yang memiliki kepandaian meramu obat dan ketangguhan ilmu bela diri yang melebihi laki-laki. Hubungan struktur ini dapat dilihat sebagai bentuk kritik Dwi Koen tentang gender. Narasi besar (grand narrative) gender memposisikan hubungan laki-laki dengan perempuan sebagai pasangan berlawanan, dimana laki-laki berada pada titik ordinat sebagai si kuat, sedangkan perempuan pada subordinat sebagai si lemah. Dalam film ini, Dwi Koen mengkritisi hal itu.

\section{c. Kulit putih versus kulit berwarna}

Seperti telah disinggung di awal, salah satu yang menarik pada film Sawung Kampret episode ini adalah hadirnya tokoh perempuan Belanda bernama Marietje. Tokoh ini berkulit putih dan berparas cantik. Tapi, kulit putih sebagai mitos kecantikan ternyata tidak berlaku dalam film ini. Melalui tokoh Sawung Kampret, kulit putih Marietje justru diidentikkan dengan hantu. Tampak di sini bagaimana Dwi Koen sedang melakukan kritik terhadap mitos kecantikan (dimana putih seperti orang Barat selalu dinilai lebih cantik dibanding wanita dengan kulit berwarna orang Timur) dengan cara memperolok-olokkannya.

\section{Hubungan Keberagaman}

Kisah ini menampilkan tokoh dalam berbagai etnis, bangsa, dimana mereka saling berelasi, baik dalam suatu hubungan harmonis maupun saling bertegangan. Nilai harmonis, dapat nyata disimak pada keluarga besar angkat Sawung, yang memiliki keragaman etnis. Selain itu nilai keberagaman juga tampak pada nama-nama tokoh, yang merupakan padu padan arti dan makna antar berbagai bahasa. Melalui hubungan struktur ini, dapat disimak bagaimana nilai keberagaman diketengahkan sebagai sinergi yang mampu menyatupadukan segala daya maupun pemaknaan, menjadi suatu ikhwal keselarasan yang berujung pada hakikat peradaban. 


\section{Relasi Tokoh Fiksi dan Nonfiksi}

Pada hubungan struktur ini, dapat disimak pada hasil uraian analisis tokoh J.P. Coen. Dalam sejarah J.P. Coen adalah tokoh heroik yang berjasa mendirikan kota Batavia, namun di mata Dwi Koen, J.P. Coen lebih sebagai sosok penghancur Batavia, yang selalu resah dengan masalah yang terkait pencitraannya. Dengan demikian struktur hubungan ini dapat dilihat sebagai bentuk kritik dan olok-olok Dwi Koen terhadap kelayakan sejarah.

\section{PENUTUP}

Berdasar analisis yang telah dilakukan di atas tampak bahwa Sawung Kampret adalah film yang memainkan elemen-elemen struktur penokohan dalam membentuk narasi bernuansa komedi. Pemberian nama Sawung Kampret pada tokoh protagonisnya menunjukkan kelucuan tersendiri. Dalam kebuda-yaan Sunda, misalnya, Sawung Kampret adalah istilah yang berasosiasi humoris, yakni sarang tempat 'burung laki-laki'. Sawung adalah sarang, sedangkan Kampret adalah sejenis burung malam (kelelawar). Dalam konteks lain, Kampret biasanya dipadankan dengan kata "celana" (celana Kampret), yakni celana dengan panjang di bawah lutut dan di atas mata kaki (sontog). Ini adalah celana yang biasa dipakai oleh para jawara (jagoan) Sunda, juga Betawi. Sedangkan dalam kebudayaan Jawa, Sawung juga berarti jagoan, pelindung, sedangkan Kampret berarti kelelawar yang memiliki asosiasi lincah dan gesit. Walhasil, dari nama tokoh utama ini saja Dwi Koen telah menyatupadukan berbagai asosiasi (bisosiasi), yang bagi penonton tertentu, terutama orang Sunda, menghadirkan kelucuan.

Namun, unsur kelucuan itu lantas tampak direlasikan dengan hal-hal serius yang bernuansa sejarah. Contoh eksplisit adalah dengan menghadirkan nama tokoh sejarah J.P.Coen. Kehadiran tokoh ini, dengan didukung fakta naratifnya, tidak bisa tidak menggiring penonton untuk mengingat kisah sejarah. Sebagaimana dicatat dalam sejarah, J.P. Coen adalah tokoh penjajah yang sekaligus dianggap berjasa membangun kota Batavia. Tidak penting apakah dalam film Sawung Kampret kisah J.P. Coen memiliki kesamaan atau tidak dengan catatan sejarah tersebut. Hal yang pasti, penyebutan nama ini segera menimbulkan asosiasi di benak penonton ke arah tokoh sejarah itu.

Fakta tersebut menunjukkan bahwa melalui film Sawung Kampret Dwi Koen telah menciptakan perspektif struktur baru dengan melakukan kritik terhadap struktur lama. Pasangan-pasangan berlawanan (binary opposition) dalam sistem lama coba dipertanyakan. Selain itu, dari hasil analisis selanjutnya, tampak pula bahwa unsur kelucuan dalam film Sawung Kampret melahirkan narasi asosiatif yang mengusung nasionalisme berdasar nilai kemanusiaan, keberagaman etnis dan budaya. Nilai dasar moral ditanamkan dengan mengajari baik buruk berdasarkan apa yang dilakukan, bukan berdasarkan perbedaan ras, bangsa, maupun status sosial; bahwa musuh Indonesia adalah penjajah Belanda, atau musuh si miskin adalah si kaya. Di samping itu, melalui keberagaman, kepekaan sosial ditajamkan, kepedulian terhadap sesama selalu diperingatkan, begitupun soal keadilan selalu didengungkan. Sedangkan ketamakan dan kemunafikan dipertunjukkan agar manusia senantiasa membuangnya.

Beberapa fakta naratif dalam struktur film Sawung Kampret sedemikian mengirim pesan bahwa film ini sedang berkisah tentang satu sisi realitas kehidupan masa lalu, yakni pada masa penjajahan, dari perspektif masa kini ala Dwi Koen. Dwi Koen melihat masa lalu (sejarah) dengan caranya sebagai komikus, sekaligus sebagai sutradara film. Kritik Dwi Koen terhadap masa lalu direpresentasikan melalui caranya memainkan struktur film se- 
bagaimana telah diuraikan. Penanaman nilai dasar moral mampu disampaikan dengan halus dan kocak, jauh dari kesan menggurui. Hingga dari keseluruhan narasi dalam struktur tersebut mendorong pada satu kesimpulan bahwa penokohan dalam film Sawung Kampret mampu membentuk suatu keutuhan narasi film menjadi sebentuk narasi kemanusiaan dan kebangsaan. Dengan demikian film Sawung Kampret dapat dikatakan sebagai film parodi sejarah yang sarat akan muatan nilai dasar moral dan nasionalisme. Melalui genre ini Dwi Koen mengangkat, memahami, mengaktualisasi, sekaligus menertawakan sejarah, dengan gaya kelakar dan sindiran khas Dwi Koen. Nilai kejenakaan sejati mampu disampaikan dengan tingkat intelegensi dan budaya kemanusiaan yang adil dan beradab relatif tinggi. Di samping itu tampak pula upaya Dwi Koen menggugah nurani masyarakat Indonesia agar semakin arif memaknai budaya tradisi bangsa, dengan memupuk semangat nasionalisme melalui bentuk kepedulian dan upaya memberi nilai baru terus menerus pada kesejatian nilai peradaban yang akarnya menancap pada sejarah. Indonesia lahir sebagai bangsa dan Negara kebudayaan. Oleh sebab itu sudah saatnya masyarakat Indonesia mampu untuk dapat lebih mencintai, menjaga, dan melestarikan nilai luhur seni budaya bangsa.

\section{Catatan Akhir}

${ }^{1}$ Hasil wawancara dengan Dwi Koen, 10 Agustus 2012. Wawancara dengan Dwi Koen dilakukan dengan bantuan Cik Dewasih untuk menjelaskan apa yang disampaikan Dwi Koen. Hal ini dikarenakan kondisi Dwi Koen yang sakit dan tidak bisa menyampaikan masukannya secara langsung dengan baik.

${ }^{2}$ Hasil wawancara dengan Dwi Koen, 5 September 2012.

${ }^{3}$ Hasil wawancara dengan Joko Nugroho, 5 Desember 2012

${ }^{4}$ Hasil wawancara dengan Dwi Koen, 9 Oktober 2012

\section{Daftar Pustaka}

Acep Iwan Saidi

2014 Bangsa Yang Mencampakkan Petani, Merusak Kebudayaan. Makalah. (tidak diterbitkan)

2008 Narasi Simbolik Seni Rupa Kontemporer Indonesia. Yogyakarta: ISAC BOOK.

Berger, Richard

2008 'Are There Any More at Home Like You?': Rewiring Superman: Journal of Adaptation in Film and Performance. 2(1): 87-101.

Cobb, Shelley

2011 Adaptation, Fidelity, and Genedered Discourses: Adaptation. 4 (1): 28-37.

Dwi Koendoro

2007 Yuk Bikin Komik. Bandung: Mizan Media Utama.

Eder, Jens

2010 Understanding Characters: Berghahn Journals. ISSN 1934-9688 (Print), ISSN 1934-9696(Online) 4 (1): 16-40.

Gordon, Ian, Mark Jancovich and Mathew

2007 Film and Comic Books. Mississipi: Association of American University Press.

Himawan Pratista

2008 Memahami Film. Yogyakarta: Home rian Pustaka.

Hutcheon, Linda

2006 A Theory of Adaptation. New York: Routledge

Lafevre, Pascal

2000 Incompatible Visual Ontologies? The Problematic Adaptation of Drawn I- 
mage. Film and Comic Books. Missisippi: Association of American University Press.

Metz, Christian

1974 Film Language: A Semiotics of the Cinema. Trans. Michael Taylor. New York: Oxford University Press.

Muhammmad Nashir Setiawan

2002 Menakar Panji Koming. Tafsiran Komik Karya Dwi Koendoro Pada Masa Reformasi Tahun 1998. Jakarta: PT Kompas MediaNusantara.

Robinson, Benjamin

2006 Batman and Batman Returns: Adapt ing A Comic Book Superhero to The Silver Screen. Thesis. California: Chapman University.

Sumber Lain:

Sigit Kurniawan

2012 Adaptasi Film ke Komik, Bakal Jadi Tren? Diunduh 5 Agustus 2014, pkl 20.45 dari http://www.the-marketeers.com/archives/adaptasi-film-kekomik-bakal-jadi-tren.html.

http://id.wikipedia.org/wiki/Si_Buta_Dari_ Gua_Hantu (2014). Diunduh 20 September 2014, pkl 21.50 wib. 